\title{
Population, Environment and Security in Port-Harcourt
}

\author{
${ }^{1}$ NNA, Nekabari Johnson, ${ }^{2}$ PABON, Baribene Gbara \\ ${ }^{1}$ PhD, ${ }^{2}$ Department of Political and Administrative Studies University of Port - Harcourt
}

\begin{abstract}
This paper examines the implication of over-population and environmental degradation on security in Port-Harcourt with the assumption that the more people seek to survive, the more intense their activities on the environment which leads to degradation. Adopting the human needs theory, it argues that the development in the city attracts people into it and therefore, causing further degradation and pollution. The city is highly populated, and the bulk, mostly unemployed youths turn to violence and crimes having been introduced to political violence by the elites. When such opportunities were no longer there, they sought for ways to make ends meet and thus, got involved in street violence and militancy. It is therefore suggested that the city be decongested by developing other towns and villages outside Port-Harcourt and relocate some of the government ministries and departments; make sporting facilities available in these localities to divert the attention of the youths from violence. The state is also required to gainfully engage the youths and stop using them as political thugs.
\end{abstract}

Key Words: Population, Environment, Human needs and Security/Insecurity.

\section{Introduction}

The growth of the world's population and the corresponding expansion of economic activities have alerted people to the fact that the earth is finite and the limits of its capacity can be reached. Resources that were adequate at lower absolute levels of demand are inadequate at higher level. Such limits challenge our ability to pursue human economic and social development while at the same time preserving the ecological system and the physical environment in general, which human development depends upon.

The world's population reached more than 6 billion in 2000, up from 2.5 billion in 1950 and the earth will need to support another 5 billion people before the human population stabilizes between 10.5 and 11 billion after 2050 (Fu,2006:256). Almost all the future population growth will be in developing states, which includes India, China, Pakistan, Nigeria, Bangladesh and Indonesia (Goldstein and Pevehouse, 2009:408). Feeding, housing and supporting such a huge population will put too much stress on land, water, energy and other natural resource.

The city of Port Harcourt was freer and easier to live in compared to what is obtainable in the present time. With less traffic and security measures in the 1970s and 1980s, people engaged in businesses and other activities freely without fear of molestation and intimidation. Population has increased tremendously in the city resulting in several activities of man which in turn has affected the environment. In recent times there has been increasing rate of crimes and criminal activities culminating to insecurity of lives and property. Such crimes include theft, burglary, kidnapping, armed robbery among others. The government expends much fund in the area of security, yet there are still pockets of threats to the security of the city.

\section{Theoretical Framework}

This paper adopts the human needs theory, which argues that the essential element required by humans to survive, goes beyond just food, water and shelter according to John Burton cited in Sandra Marker (2003:1). They include physical and non-physical elements needed for human growth and developments as well as those things human are driven to attain. The need for textiles, machines, vehicles and other equipment propels man into production process or processes. These activities in one way or the other emit gases that are dangerous to the health of humans. Cutting down trees and clearing green vegetations that are useful to man in his day to day life results in deforestation. Human needs are sought simultaneously in an intense and relentless manner and when the resources or environment has been exhausted, man becomes frustrated and thereafter aggressive to those he feels are responsible. The human needs theory is suited in this paper as it exposes us to the fact that it is the need of man that makes him explore and exploit the environment which in turn gives rise to frustration of man when the needed resources are no longer available in the required number or quantity. Sandra (2003:1) maintains that human needs are the primary causes of protracted or intractable conflict. It results from the people unyielding drive to meet their unmet needs on the individual, group, and societal level.

The paper is divided into five segments - introduction, review of literature, security in Port-Harcourt, conclusion and suggestions, for a way forward. 


\section{Review Of Literature}

After some decades of debate and analysis scholars are beginning to develop much clearer answers to complex questions regarding how population changes and environmental degradation affect security concerns.

Thomas Robert Malthus recognised a potential population problem and pointed to a key relationship between population growth and food production. According to him, if population grows unchecked it will increase at a geometric rate [progression] $(1,2,4,8,16 \ldots)$ Mingst (2004). He thus maintain that population increase will outstrip food production. However, such increase would not just lead to scarcity of food except the bulk of the population are dependants. Where the bulk of the population constitutes the labour force, food resources would be available but would lead to scarce resources as there will be too many hands to scramble for available ones. Land for food production will not be sufficiently available leading to an over- use of the readily available ones. This trend leads to degradation of the environment.

On his part, Porter (1995) observes that environmental security rest primarily on evidence that there is serious degradation of natural resources (biological diversity, fresh water, soil, and forest and fishery resources) and vital life-support system (the ozone layer, climate system, oceans and atmosphere) as a result of the recent acceleration of global economic activities. The thinning of the stratospheric ozone layer because of the accumulation of certain man-made chemicals has a severe impact on human health and nutrition. Increase concentration of carbon dioxide and other gases that trap heat in the atmosphere could alter the fundamental physical condition of life on the planet, causing climate warming.

The health of the world economy itself depends on avoiding the depletion of renewable natural resources. The degradation of cultivated land threatens to reduce agricultural productivity in large areas of high population in the developing world. More so, the loss of biodiversity, one of human's chief resources for coping with diseases and other unexpected natural changes, would reduce the chances of discovering natural substances that might hold the cure for existing and future diseases (Porter, 1995). The importance of human health is threatened by the depletion of renewable resources, degradation of cultivated land as it affects agricultural productivity and loss of biodiversity.

Kaplan (1994) examined the issue of overpopulation, environmental degradation, crime, disease and beautifully presented his case stating that "it was time to understand the environment for what it is...the national security issue of the early twenty-first century". The political and strategic impact of surging population, spreading diseases and soil erosion, water depletion, air pollution and possibly rising sea levels in critical overcrowded regions will prompt mass migration and in turn incite group conflict. Pointing to Homer Dixon's view of future wars and civil violence which will often arise from scarcity of resources such as water, cropland, forest and fish just as there will be environmentally driven wars and refugee flow, he asserts that nation's democratising tendencies are likely to be superficial, having to do with long time processes that includes souring population and shrinking raw materials (Kaplan, 1994). According to him, Homer Dixon concludes that as environmental degradation proceeds, the size of the potential social disruption will increase. He predicts that nature was coming back with a vengeance, tied to population growth and will have incredible security implications. 'The worst degradation is generally where population is high'.

Goldstone (2002) asserts that population growth often brings degradation of forest, water resources, arable land and other local resources. He expressed that such environmental degradation is not a major or widespread of international wars, ethnic wars or revolutionary conflicts. Such degradation often brings misery, yet such misery does not generally trigger the elite's alienation and opposition to the government necessary for a large scale violence to occur. However, in one of his propositions, he submits that population growth can give rise to conflict over increasingly scarce resources such as farmland, if those conflicts involve elites seeking to take resources from popular group or competition between elite faction for control of those resources. Thus, what determines whether conflict arises are the relationships among popular groups, elites and the state and particularly whether the state has the capacity to channel and moderate elite conflicts? Only where elite conflict or popular resistance to elite's actions overwhelm weak states, do major conflicts arise.

Alex de Sherbinen's view reveals that the impact of population change on conflict only in terms of overall population growth is too simple to capture the complex relationship involved. Rather, it is particular kind of demographic changes occurring in particular political and economic context that cause instability. What is therefore obtainable in the cases of China, Latin America and Europe mostly where there is no environmental degradation is likely to be different from this part where there is degradation alongside other factors capable of instigating violent crisis (Goldstone, 2002).

The implication of the foregoing is that there is a complex related factor responsible for violent conflicts. They include an expanding urban population in an economy that is not providing commensurate economic growth; an expanding population of highly educated youth facing limited opportunities to obtain elite political and economic position; large youth bulge, an expansion of the 15 to 25 cohort relative to the overall adult population of a society, especially where political institutions are weak. 


\section{Security/Insecurity In Port-Harcourt}

Port-Harcourt the capital city of Rivers State is located in the Niger Delta Region of Nigeria with more than five ethnic groups or nationalities. What is literally known as Port-Harcourt today include Obio/Akpor - a sister local government area. In this study therefore, Port-Harcourt and Obio/Akpor are generally referred as 'Port-Harcourt'.

The city serves as the commercial nerve centre of the state and has over the years witnessed an influx of migrants from the rural communities where farmland have been destroyed as a result of oil exploration and exploitation by multinational oil firms. Such areas include Ogoni, Etche, Abua and Ikwerre among others. In Ogoni for instance, oil pipelines criss-cross the farmland with oil spills rendering arable land infertile. According to Nna and Ibaba (2011:107) oil mineral producing communities are faced with the degrading effect of oil exploration and exploitation, their lands, streams and creeks are continually polluted; the atmosphere charged with hydro-carbons and carbon monoxide; several other villages experience gas flares a few meters from their residential houses, for example Dere (Bomu oil field) and Rumuola in Port Harcourt. With these occurrences, farmers hardly produce enough food crops for consumption. The people rather depend on produce from other parts of the country with little resources (money) at their disposal, for purchase. Gas flaring in these areas has also affected plants, trees, farmland, and water sources alike leaving the people with the alternative of migrating into the city in search of greener pasture or white-collar jobs. Kegley and Wittkopf (1995:135) asserts that the hope for a better life in the urban areas led to a flood of migrants from farm to city, resulting in decrepit urban slums with massive numbers of unemployed seeking to in the small industrial sector.

The city is important as it is the centre of social and economic life of the state and thus highly congested. The city is a major industrial centre as it has a large number of multinational firms as well as other industrial concerns, particularly business related to petroleum industry. In 1973, a social survey found that migrants made up of 72 percent of Port-Harcourt's population, and from an area of $15.54 \mathrm{~km}^{2}$ in 1914 , it grew uncontrolled to an area of $360 \mathrm{~km}^{2}$ in the $1980 \mathrm{~s}$ (www.wikipedia.org).

The population of the city is as indicated in the tables below based on the 1991 and 2006 census figures.

Table 1 showing population figures of Port-Harcourt before the creation of Obio/Akpor Local Government Area.

\begin{tabular}{|l|l|}
\hline Sex & 1991 figure \\
\hline Male & 232,181 \\
\hline Female & 208,218 \\
\hline Total & 440,399 \\
\hline
\end{tabular}

Source: National Population Commission, Port Harcourt.

Table 2 showing the population of 'Port-Harcourt' as per 2006 census figures

\begin{tabular}{|l|l|l|l|}
\hline L.G.A. & SEX & 2006 Figure & TOTAL \\
\hline \multirow{2}{*}{ Obio/Akpor } & Male & 244,875 & 464,789 \\
\cline { 2 - 3 } & Female & 219,914 & \\
\hline Port-Harcourt & Male & 276,464 & 541,115 \\
\cline { 2 - 3 } & Female & 264,651 & \\
\hline \multicolumn{2}{|l|}{ Grand Total } & & $1,005,904$ \\
\hline
\end{tabular}

\section{Source: National Population Commission, Port Harcourt.}

From the above, there is an increase in the population of the city. The figure of Port-Harcourt alone as per the 2006 census $(541,115)$ is $10.3 \%$ higher and above the 1991 figure. However, the total population of PortHarcourt and Obio/Akpo as per 2006 is 1,005,904. This figure is considered in the study as the two Local Government Areas are put under study.

The area that became Port-Harcourt in 1913 was originally the farmland of Diobu village group of Ikwerre and what is known as the main town. But the city later absorbed Oroworukwo, Nkpolu, Rumuomasi. It now includes Rumuokoro, Rumuolumeni, Rumuopirikom, and Rumuodomaya, Rukpokwu, Rumuogholu stretching to Choba. Dr. Nmegbu in an interview, point to the indicators of population increase such as influx of people from other parts of the country into the city, congestions, pollution and increase in waste and dump sites. According to him, development leads man to tamper with the environment causing harm to aquatic life. It also causes harm to animals and makes man suffer from direct heat from the sun as a result of deforestation. Again, grading or excavation of the environment causes pollution. He further maintained that the more of man's activities to bring about development, the more polluted the environment would be. The need for development leads to expansion of the city to the extent that a new-comer into the city today can hardly differentiate between the two Local Governments of Port Harcourt and Obio/Akpo but would only see everywhere as Port Harcourt.

With the increase in population and congestion in the city, there is an attendant increase in the cost of living. There is increase in rent resulting from high demand for accommodation thereby making it a scarce 
Population, Environment And Security In Port-Harcourt

'commodity'. What Olaniyi (2010) call acute shortage of accommodation. To this end, the cost of rent has increased over time. Table 3 for instance shows the cost of rent in different locations in Port - Harcourt in recent time.

\begin{tabular}{|c|c|c|c|c|}
\hline S/No & Name of locations & 1 room & 1 bedroom flat & 2 bedroom flat \\
\hline 1 & Ogbogoro & $\begin{array}{l}\mathrm{N} 3,000-\mathrm{N} 4,000 \text { per } \\
\text { month }\end{array}$ & $\begin{array}{l}\text { N100,000-N120,000 } \\
\text { per year }\end{array}$ & $\begin{array}{l}\text { N150,000- } \\
\text { N160,000 per year }\end{array}$ \\
\hline 2 & Iwofe & $\begin{array}{l}\mathrm{N} 42,000-\mathrm{N} 48,000 \\
\text { per year }\end{array}$ & $\begin{array}{l}\text { N150,000-N170,000 } \\
\text { per year }\end{array}$ & $\begin{array}{l}\mathrm{N} 230,000 \\
\mathrm{~N} 270,000 \text { per year }\end{array}$ \\
\hline 3 & Rukpokwu & $\begin{array}{l}\text { N5,000-N6,000 per } \\
\text { month }\end{array}$ & $\begin{array}{l}\text { N150,000-N160,000 } \\
\text { per year }\end{array}$ & $\begin{array}{l}\mathrm{N} 250,000 \\
\mathrm{~N} 270,000 \text { per year }\end{array}$ \\
\hline 4 & Eneka & $\begin{array}{l}\text { N5,000-N6,000 per } \\
\text { month }\end{array}$ & $\begin{array}{l}\text { N150,000-N160,000 } \\
\text { per year }\end{array}$ & $\begin{array}{l}\mathrm{N} 250,000 \\
\mathrm{~N} 270,000 \text { per year }\end{array}$ \\
\hline 5 & Alakahia & N6,000 per month & $\begin{array}{l}\mathrm{N} 180,000-\mathrm{N} 190,000 \\
\text { per year }\end{array}$ & $\begin{array}{l}\mathrm{N} 250,000 \\
\mathrm{~N} 280,000 \text { per year }\end{array}$ \\
\hline 6 & Choba & $\mathrm{N} 6,000$ per month & $\begin{array}{l}\text { N180,000 } \\
\text { per year }\end{array}$ & $\begin{array}{l}\mathrm{N} 250,000 \\
\mathrm{~N} 280,000 \text { per year }\end{array}$ \\
\hline 7 & Rumuigbo & $\begin{array}{ll}\text { N5,000-N6,000 per } \\
\text { month }\end{array}$ & $\begin{array}{l}\text { N150,000 } \\
\text { per year }\end{array}$ & $\begin{array}{l}\mathrm{N} 250,000 \\
\mathrm{~N} 300,000 \text { per year }\end{array}$ \\
\hline 8 & Eleparanwo & & $\begin{array}{l}\text { N140,000 } \\
\text { per year }\end{array}$ & $\begin{array}{l}\mathrm{N} 200,000 \\
\mathrm{~N} 2500,000 \\
\text { year }\end{array}$ \\
\hline 9 & Main Town & $\begin{array}{l}\mathrm{N} 3,000 \text { - N5,000 per } \\
\text { month }\end{array}$ & $\mathrm{N} 120,000-\mathrm{N} 150,000$ & $\begin{array}{l}\mathrm{N} 200,000 \\
\mathrm{~N} 230,000\end{array}$ \\
\hline
\end{tabular}

Source: Researcher's field survey (2010)

In summation, rent for a room now goes for N50,000 per year as against N18,000 in the 1990s, a one bedroom flat now goes for an average of between N150,000 and N200,000 as against N36,000 - N40,000 and two bedroom flat now goes for an average of between N230,000 - N300,000.

However, from the above table, the cost of accommodation varies based on locations and facilities available. Such facilities include water, power (electricity) and the decency of the environment. Some argue that the structures found in the new areas that constitute 'Port-Harcourt' are modern in terms of design and otherwise compared to what was in the past as found in the main town. For this reason, some of the structures in town are being re-structured to fit the modern times.

Food prices are high as compared to what was obtainable in the 1970s and 1980s. One basin of Garri now cost between N1, $600-\mathrm{N} 1,800$ as compared to some shillings in the 70s and few naira in the 80s. Farmland is now being sold to 'strangers' and causing scarcity of that resource in relation to farmers' activities as discovered for example, in Eneka, Iwofe, Eleparanwo, Rukpokwu, etc. The enlargement of the city with a high population has brought about scarcity of land and food as there are few available ones. In Eneka for instance, some of those who sold land to people turn to these buys and seek for its use for farming pending the development of such plots. This shows that some are beginning to lose land which was in abundance for farming activities.

Pollution is extant as the quality of geographic space diminishes, resulting from pressure - noise pollution and discharge of gases dangerous to human health from waste dump sites. The water channels are filled with waste industrial and human - making it unhealthy for fishing practices. For instance the 'Ntawoba' creek that cuts across D line onto Aba road through old GRA is filled with waste that does not allow water to flow properly. Again, the Rumuogholu - Rumuokoro -Eliozu - Rumuodara water ways are filled with waste that prevents free flow of water. Industrial activities have also contributed to the degradation and depletion of the environment as the industries discharge waste indiscriminately into the creeks as well. For instance the companies in Trans-Amadi industrial area discharge waste indiscriminately into the river. Evidence abounds in the Wajah creek, Azuabie creek, Oginigba creek all in the Trans-Amadi industrial area. Wilbros now ASCOT in Choba with abandoned old boats and other metals in the Choba creek hinder decent fishing practices. With these activities the people no longer engage in serious fishing business as was the practice before.

Fishing and farming which are the primary occupations of the people are no longer practiced to the fullest as a result of environmental degradation. A report according to Olaniyi (2010) states that the people are mostly farmers and hunters...[fishermen] and most of the companies, which include some key oil and gas firms, cannot satisfy the employment needs of the teeming population. The disconnect between the people and their source of livelihood without provision for another makes them, especially the youths, idle and thus, are easily used or lured into crimes and violence as well as being used as political thugs by elites. Because they are mostly young people who have fewer responsibilities for families and careers, they are relatively easily mobilised for social and political conflicts. The relationship between these youth bulge and the elites that causes conflict is 
what Goldstone (2002) describes in these words: "in order for popular discontent or distress to create large-scale conflicts there must be some elites leadership to mobilise popular groups and to create linkages between them". An interviews conducted buttressed this when they said the elite politicians created a link between groups [cult groups] in different parts of the city for their selfish gains and abandoned them to their shanty homes in the waterfronts and other parts of the city. The elites, once in office either abandon the well-armed gangs to their own devices or continue using them to intimidate their opponents and carry out criminal activity such as bunkering.

Having tasted 'milk and honey' and do not have the opportunity again, the groups, re-group and engage in illegal activities such as oil bunkering, burglary, theft and the likes. They are exposed to the fact that money could be made in different ways including kidnapping for ransom. According to Wosu and Anele (2010:213) [the] youths engage themselves in all kinds of illegitimate activities for survival. Out of desperation, they got involved in ... smoking and sale of opium (Indian hem). Others are commercial sex, robbery, cultism and political thuggery during elections. A human rights report has it that in the year since 2003 elections, gang violence has steadily increased. Gangs have amassed revenue through involvement in illegal activities ranging from bunkering trade in stolen crude oil, bank robberies to kidnappings, among others.

Their relationship with the elites has opened their eyes to the gap between them. The differential in economic growth rates, along with the widening gap between rich and poor, are producing dangerous fissures in many societies. As the masses of poor see their chances of escaping acute poverty diminish, they are likely to become increasingly resentful of those whose growing wealth is evident. This resentment is especially pronounced in the impoverished shanty towns and waterfronts. In these inhospitable surroundings, large numbers of people - especially among the growing legions of unemployed youths - are being attracted to extremist political movements or to street gangs and drug trafficking syndicates.

The presence of these youths in shanty towns or homes, points to the fact that the state structure is simply unable to cope with the demands of housing and feeding the growing population. The 'survival of the fittest' approach to life is therefore the option for them and the result is an increase in crime in relation to what used to be in the 1980s and 1990s. There has been tremendous increase in crimes over the period 2006 to 2010 while the security agents have taken measures to check or control the occurrences of others.

Table showing some selected crimes and their total occurrences for the years $2006-2010$.

\begin{tabular}{|l|l|l|l|l|l|l|}
\hline S/No & Type of crime & $\begin{array}{l}\text { Total } \\
\text { occurrence } \\
2006\end{array}$ & 2007 & 2008 & 2009 & 2010 \\
\hline $\mathbf{1}$ & Assault & $\mathbf{1 , 7 8 4}$ & $\mathbf{1 7 6 4}$ & $\mathbf{1 6 4 9}$ & $\mathbf{9 3 9}$ & $\mathbf{4 0 8}$ \\
\hline $\mathbf{2}$ & $\begin{array}{l}\text { Grievous harm } \\
\text { and wounding }\end{array}$ & $\mathbf{2 2 4}$ & $\mathbf{1 5 2}$ & $\mathbf{1 1 3}$ & $\mathbf{1 0 2}$ & $\mathbf{9 6}$ \\
\hline $\mathbf{3}$ & Murder & $\mathbf{7 6}$ & $\mathbf{7 6}$ & $\mathbf{5 7}$ & $\mathbf{4 2}$ & $\mathbf{4 6}$ \\
\hline $\mathbf{4}$ & $\begin{array}{l}\text { Rape and indecent } \\
\text { assault }\end{array}$ & $\mathbf{9 9}$ & $\mathbf{7 3}$ & $\mathbf{4 7}$ & $\mathbf{2 1}$ & $\mathbf{2 0}$ \\
\hline $\mathbf{5}$ & Kidnapping & $\mathbf{1 7}$ & $\mathbf{2 0}$ & $\mathbf{3 0}$ & $\mathbf{0 5}$ & $\mathbf{1 1 2}$ \\
\hline $\mathbf{6}$ & Armed robbery & $\mathbf{1 3 8}$ & $\mathbf{1 4 5}$ & $\mathbf{1 2 2}$ & $\mathbf{8 9}$ & $*$ \\
\hline $\mathbf{7}$ & Theft and stealing & $\mathbf{1 , 8 2 4}$ & $\mathbf{1 , 3 9 5}$ & $\mathbf{1 , 3 6 1}$ & $\mathbf{9 1 6}$ & $*$ \\
\hline $\mathbf{8}$ & $\begin{array}{l}\text { Burglary, House } \\
\text { and Store breaking }\end{array}$ & $\mathbf{2 0 2}$ & $\mathbf{1 3 4}$ & $\mathbf{9 4}$ & $\mathbf{1 0 8}$ & $*$ \\
\hline $\mathbf{9}$ & $\begin{array}{l}\text { Breach of public } \\
\text { peace }\end{array}$ & $\mathbf{2 6 1}$ & $\mathbf{2 4 3}$ & $\mathbf{2 1 4}$ & $*$ & $*$ \\
\hline Total & & $\mathbf{4 , 6 2 5}$ & $\mathbf{4 , 0 0 2}$ & $\mathbf{3 , 6 8 7}$ & $\mathbf{2 , 2 2 2}$ & $\mathbf{6 8 2}$ \\
\hline
\end{tabular}

Source: Nigerian Police Force, Rivers State Command (2010).

* Not available on official record for the year 2010

From the figures in the table, crime rate was at its peak in 2006 with a total of 4,625 of the selected crimes. The decline in reported crime rate is as a result of the strategies employed by the security agents in tackling them. The Rivers State Police Commissioner Mr. Suleiman Abba, in a radio interview confirmed the arrest of sixty one (61) armed robbers and 19 kidnappers in the month of June 2011. He emphasised that ten (10) armed robbers and six (6) kidnappers were wounded while several armed robbery attempts were foiled. The rate of crime was not as high as this in the 1980s and early 1990s according to Nmegbu who bore his mind on the issue. He maintained that Port-Harcourt was sparsely populated then and one dump site served for one or two years before they were filled up. The crime rate increased with the expanding population in the city.

Growing population puts more strain on resources, and exacerbate conflicts over natural resources. So do a range of issues such as over-fishing, deforestation and loss of agricultural land to urban spread. The pursuit of human needs leads to activities that often affect the environment negatively thereby causing degradation - 
excavation, gas emission by industries during production of goods required by man. The threatening capacity of environmental degradation can be compared to both military and economic threats in its ability not only to affect interest of states but the very interest of individuals and the communities. This is because ecological damage can damage the physical base of states to a sufficient extent to threaten their ideas and institutions.

\section{Conclusion And Recommendation}

Despite slow-downs or drop in overall growth, many countries may well experience collision between their agrarian population and access to land, between the expansion of their labour force, educated aspiring elites, urban population and youth cohorts and the absorption of their economies; and between migrants and resident population that inflame ethnic and regional tensions.

The environment has been a relatively constant background factor in conflict rather than an issue in its own right. Environmental degradation is a background or triggering factor in the conflict or insecurity situation in the city coupled with the inability of the government to provide gainful employment for these youth bulge. These situation with socio-political factors leads the youth to violence as a means of survival.

The economic activities of human kind since the industrial revolution have created problems for the survival of all forms of life. As the population increased, so also have the levels of human economic activities. Thus, the increase in population with a corresponding increase in human economic activities and their consequent impact on the environment are visibly retarding the conditions of life. There is a cause and effect relationship between human economic activities and the damage done to the environment. The ecosystem, the land, the ozone layer was and is still being degraded or depleted by human pursuit of development.

The reason behind the Rivers State Government's idea to demolish the waterfronts in Port-Harcourt is not far-fetched. The presence of overblown population in these poor, shanties, shabby buildings and their conditions of life calls for concern. One can hardly take statistics of genuine activities going on in such places. Not even parents can give account of the activities of their children and wards. Such areas are highly populated and serve as hide-outs for criminals and or hoodlums, for example, the 'Bundu' waterfront, 'Egede' waterfront, 'Abuja' waterfront, off creek road, Ogbumnobali waterside, etc. These youths operate in the urban centres and their environs and escape to their hideouts in the creeks, slums (waterfronts) where they are hardly located or any form of their identity disclosed. Apart from the waterfronts, other parts of Port-Harcourt is overpopulated because of the presence of migrants from the rural areas and other parts of the country, and the kind of buildings and activities going on there.

Population explosion, environmental degradation among others leads to scarcities of food as there are too many mouths to consume the available ones. Scarcity of arable land also results as industries have taken over agricultural land. A case in point is the Trans-Amadi area and other parts of the city. The activities of these industries results in environmental degradation, which Kaplan argues, is a part of a terrifying array of problems that will define [is defining] a new threat to our society. Teng Fu (2006) submits that unrestrained human activities are the root causes of many environmental problems.

Increasing population densities, industrial and socio-political activities combined with unsound agricultural practices, as a result of inhibiting factors, breeds insecurity - food insecurity, health insecurity and the likes. A densely populated city as Port-Harcourt with degraded environment or depletion of resources leads to insecurity, indicating that there is a relationship between population increase, environmental degradation and security.

\section{RECOMMENDATIONS}

Following the spate of violence and insecurity in the city - food, health and social insecurity - the first step to ensuring a reduction in the population is to develop other towns and villages outside Port-Harcourt, for instance Ahoada, Bori, Etche, Degema, Eleele and Isiokpo.

There is the dire need to re-locate some of the state government ministries and or Departments to these towns to decongest Port-Harcourt. With this in place, workers or civil servants would decide to relocate to the areas where their ministries and departments are situated to enable them attend to their duties effectively.

It is also suggested that laws and or edicts to regulate the conduct of multinational corporations in waste disposal and management be enacted, if there are none, and effective monitoring of these companies to ensure compliance. This will make for the avoidance of reckless waste disposal. They should be made to adopt environment friendly policies and stop gas flaring as currently being practiced. Till date, gas is being flared at the Eleme Petrochemical industries (Indorama) and the Eleme Refinery Company (NNPC) and at a Shell location at Aluu near Choba, among others. Also, Multinational Corporations be made to take Corporate Social Responsibilities (C. S. R.) seriously so as to compliment government efforts at providing amenities to its citizenry at the grassroots levels.

Employment opportunities are made available to its teeming population especially the youths who are vulnerable and prone to violence and thuggery. Provision of infrastructure that has direct bearing on the lives of the citizens is also required to be on ground to make life comfortable and meaningful. Such infrastructure 
includes electricity or power which will give room for the people to engage in businesses Small and Medium Enterprises (SMEs). For example, welding, dry cleaning services, sales of drink among others are likely businesses people would get involved in. This is strongly advocated as it diverts the attention of the youths from violence to meaningful ventures. The presence of electricity also keeps the youths glued their television sets as they view programmes of their interest and watching home video, thus consuming their time they would use to perpetuate street violence or crimes in general.

To also curb the violence perpetuated by the youths, it is suggested that the government in collaboration with private individuals and companies build sporting facilities in the Local Government Areas to encourage youth participation in sports as to keep them busy. Looking around the world today, sports, especially football, is a factor that unites people and thus should be taken seriously. Building of stadium where football matches could be played often, would keep the minds of the youths off crimes, gangstarism, street violence and or violence in general.

Lastly, political elites should desist from using the youths for political violence and or thuggery as it does not portend any good for our society and the political system.

\section{References}

[1] Bakut, T.B, The Environment, Peace and Conflict in Africa in Gaya Best (Ed) Peace and Conflict Studies in West Africa. (Ibadan: Spectrum Books limited 2006).

[2] Goldstein, J.S and Pevehouse J.C, International relations (Boston:Longman publishers, 2009)

[3] Goldstone J.A (2002) "Population and Security: How Demographic change can lead to violent conflict" in Journal of International affairs, Vol.56,No. 1. New York: Columbia University (www.mafhoum.com)

[4] Hartmann Best (1998) "Population, Environment and Security: a new trinity" in Environment and Urbanisation Vol.10, No. 2 October, 1998.

[5] Kaplan R. (1994), "Redefining Security: The New Global Schism” in Journal of Current History.

[6] Kegley C. W. Jr and Wittkopf E.R, World Politics: Trend and Transformation (New York: St. Martin's Press Inc. 1995)

[7] Mingst, K.A, Essentials of International Relations (U.S.A: W.W. Norton and company (2004),

[8] Nna, J.N and Ibaba, S.I (Eds) Crisis and Development in the Niger Delta: SelectedWorks of Kimse Okoko. (Nigeria: University of Port Harcourt, 2011)

[9] Olaniyi, B, How Rivers Council Was Transformed” in The Nation. Vol.5, No. 1570, Friday, 5 2010 pp.39-40

[10] Russet B. et'al, World Politics: The Menu choice. (Canada: Wordsworth publishers 2006),

[11] Sandra Marker, Unmet Human Needs www.beyondintractability.org (2003) retrieved $26^{\text {th }}$ July 2012 pp. 1-5

[12] Teng,Fu, “GlobalisationandtheEnvironment”inMaryan,C.L.(Ed)BeyondSovereignty.(Canada:Wordsworth Publishers, 2006)

[13] "The Human Rights Impact and causes of Post-Election Violence in Rivers State, Nigeria" www.hrw.org/en retrieved 17th March 2011.

[14] Wosu E. and Anele K. (2010) "Rural-Urban Migration of Young Person from selectedconflict ridden communities in Rivers State: A sociological approach".www.academicjournals.org/ajpsir retrieved 11th March 2011. 